\title{
How Berkeley Corrupted His Capacity to Conceive
}

Berkeley challenges his readers to conceive of a body existing independently of a mind.

"But," as Ramsey used to say to Wittgenstein, "it just is possible to think of such a thing"

(Zettel \$272). Ramsey seems to have had an infinite row of trees in mind, but it's his

emphasis that I'm invoking. It just is possible to think of a body existing independently of

the mind. As Ian Tipton remarks, "the reader has been challenged to do a certain trick and

he does it without any difficulty at all' (158). Why couldn't Berkeley manage it?

In Reason, Truth, and History, Hilary Putnam writes,

To state Berkeley's conclusion another way, Nothing can be similar to a sensation

or image except another sensation or image. Given this, and given the (still

unquestioned) assumption that the mechanism of reference is similitude

between our 'ideas' (i.e. our images or 'phantasms') and what they represent,

it at once follows that no 'idea' (mental image) can represent or refer to

anything but another image or sensation (59).

Putnam is right, I want to show, and this gets at the heart of the our puzzle.

My plan is to begin by examining an argument that Philonous offers to show that we can't have an idea of unperceiving matter. Next I'll explain why Berkeley thinks that if we have no idea of matter, then we can't conceive of matter at all. I'll then apply lessons learned to re-interpreting Berkeley's master argument and conclude that his theory of representation corrupted his capacity to conceive.

\section{The Resemblance Argument}

In the Three Dialogues, Berkeley offers the following argument

If it be allowed that no idea nor any thing like an idea can inhere in an unperceiving substance, then surely it follows, that no figure or mode of extension, which we can either perceive or imagine, or have any idea of, can be really inherent in matter; not to mention the peculiar difficulty there must 
be, in conceiving a material substance, prior to and distinct from extension, to be the substratum of extension" (3D 2.190). ${ }^{1}$

The explicit premise is that no idea and nothing that resembles an idea can inhere in an unperceiving substance. The explicit conclusion is that we can't have an idea of extension

that represents a quality inhering in an unperceiving substance. An implicit premise is that if we have an idea of extension that represents a quality inhering in an unperceiving substance, then it resembles that quality. This is enough to make the initial part of the argument valid, and it fits, as we shall see, with the rest of Berkeley's theory of representation.

For conceptual clarity, it might be useful to divide the explicit premise (no idea nor any thing like an idea can exist in an unperceiving substance) into two: first, ideas only resemble ideas; and second, ideas don't inhere in unthinking matter.

After the explicit premise is divided in two and the implicit premise made explicit, what I want to call Berkeley's resemblance argument shakes out as follows:

1. Ideas only resemble other ideas

2. No idea inheres in a mind-independent body.

3. If we have an idea of extension that represents a quality inhering in a mindindependent body, our idea of extension resembles something inhering in a mindindependent body.

4. So we don't have an idea of extension that represents a quality inhering in a mindindependent body.

\footnotetext{
${ }^{1}$ References to the Three Dialogues (3D), Alciphron, and Berkeley's sermons are to volume and page of The Works of George Berkeley, Bishop of Cloyne, edited by A. A. Luce and T. E. Jessop. London: Thomas Nelson and Sons, 1978. References to Berkeley's notebooks are to entry numbers. Other references to Berkeley are to section numbers. For The Principles of Human Knowledge (PHK), my references are to sections in Part I. References to Locke's Essay Concerning Human Understanding are to Book, Chapter, and Section. My reference to Descartes is first to volume and page of the Adam and Tannery edition of Oeuvres de Descartes (Paris: Vrin, 1904) and then to volume and page of the Cottingham, Stoothoff, and Murdoch's edition of The Philosophical Writings of Descartes (Cambridge: Cambridge University Press, 1984). My reference to the Leibniz-Clarke Correspondence is first to page number in H.G. Alexander's edition (Manchester: Manchester University Press, 1956) and then to volume and page number of Gerhardt's edition of Die Philosophischen Schriften von Gottfried Wilhelm Leibniz. (Hildesheim: Georg Olms Verlag, 1996). I used J.A. Smith's translation of de Anima as it stands in Richard McKeon's edition of The Basic Works of Aristotle (New York: Random House, 1941). I modified some of the translations. I'm grateful to Walter Ott for inviting me to present this material at his conference, I had useful conversations with Jan Cover on the topic, Chris Pincock helped me find the passage about Ramsey in Zettel, and Eric Sotnak gave me a helpful comment.
} 
The first premise has attracted sufficient attention, perhaps. ${ }^{2}$ Berkeley thinks the proposition is obvious (PHK \8), but for those who don't he offers various arguments. A sensible thing such as an idea can't resemble an insensible thing (PHK \8, 3D 2.206). A fleeting thing can't resemble an enduring mind-independent thing (PHK §14, 3D 2.205). More narrowly, ideas of sight don't resemble objects at a distance, since appearances alter radically as we walk toward the object (New Theory of Vision \$44).

Perhaps no conclusion in the history of philosophy has been as persuasive. Not only has Berkeley convinced almost all current philosophers that ideas only could resemble other ideas, but he has convinced many historians of philosophy that it's uncharitable to think that anyone ever denied it. ${ }^{3}$ It's as if Berkeley convinced his opponents retroactively.

With respect to the second premise, Berkeley takes the proposition that ideas might inhere in mind-independent bodies to be a contradiction (PHK \$7, 3D 2.195). "To have an idea is all one as to perceive," he argues, so if ideas inhere in something than that thing “must perceive them” (PHK \$7). Certainly on the Cartesian conception of idea, ideas are modes of thinking substances and cannot inhere in unthinking bodies. Phillip Cummins interprets Berkeleian ideas as just whichever qualities we perceive immediately, e.g. colors, sounds, sizes, and shapes (1968 361). Cummins claims that it's an advantage of this reading that it implies that Berkeley's arguments "are not dependent upon any theory of ideas" (ibid.). On the other hand, the premise that ideas don't inhere in mind-independent bodies is quite dubious if we pluck Berkeley's theory of ideas from its historical context in this manner.

\footnotetext{
${ }^{2}$ For discussions, see Turbayne 1956, Cummins 1968, Pitcher 115-20, Winkler 1989 140-49, and Ryan 2006. ${ }^{3}$ I have in mind Bennett (1971 106) and Curley (1972 451). Bennett backed off this claim somewhat in his "A Note on Interpretation." I misdescribed Bennett's toned-down position in Jacovides (2007 106), which I regret.
} 
Let me turn to the third premise, that if we had an idea of mind-independent body, our idea of extension would resemble something inhering in that body. For Berkeley, as for most of his predecessors, the central form of representation is resemblance. ${ }^{4}$ His commitment to the principle that ideas represent through resemblance comes out in $\$ 33$ of the Principles: "Real things" are ideas imprinted by God. Ideas "excited in the imagination" are "more properly termed ideas, or images of things, which they copy and represent." 'Properly' here means distinctively or specially. ${ }^{5}$ Ideas excited in the imagination are ideas narrowly socalled. When Berkeley writes that they are 'images of things' he means that they are close resemblances of them (Winkler 1989: 10). The corresponding passage in Notebook A reads: “properly speaking Idea is the picture of the Imagination's making this is $\mathrm{y}^{\mathrm{e}}$ likeness of \& refer'd to the real Idea or (if you will) thing" (\#657a). These ideas, narrowly so-called, represent real things by copying and resembling them.

So, for example, you look before you and you see a lectern. The lectern is a real thing and a collection of ideas, broadly so-called. When you close your eyes and think back on that lectern, you form a mental image of it, which is an idea narrowly so-called and represents the lectern by being a copy of it.

Ken Winkler cites $\$ 33$ of the Principles, along with $\$ \int 8$ and 87 and the draft introduction and concludes that for Berkeley, "all thinking about things is representational, and the mechanism of representation is resemblance or similitude" (1989 14, cf. Winkler 2005 126-38). Winkler supplements this claim with a theory of signification according to which words and other ideas can come to represent objects with which they've been

\footnotetext{
${ }^{4}$ Putnam emphasizes the significance of this fact for understanding Berkeley: "the premiss from which Berkeley worked — the similitude theory — was not something he merely learned from Locke (or read into Locke) but was the accepted theory of reference before his time and, indeed, for a hundred years afterwards" (59).

${ }^{5}$ Cf. OED sv 'properly' $1 \mathrm{~b}$.
} 
associated and words can come to signify by their place in a predictive system (1989 14-21, 2005). Notwithstanding such subtleties, the non-arbitrary backbone of Berkeley's theory of representation is resemblance.

Berkeley's premise that representation works through resemblance has a long tradition behind it. Aristotle begins many of his works by summarizing the views of his predecessors. In his summary at the beginning of de Anima, he reports that, with one exception, those who define the soul by its capacity to know believe that "like is known by like; as the soul knows everything, they construct it out of all the principles" (405b12-16). "The exception," he writes, "is Anaxagoras; he alone says that mind is impassible and has nothing in common with anything else. But, if this is so, how or in virtue of what cause can it know? That Anaxagoras has not explained, nor can any answer be inferred from his words" (405b20-23). ${ }^{6} \quad$ Some version of this doctrine was adopted by most of Aristotle's scholastic followers. ${ }^{7}$ Few commentators would interpret Thomas Aquinas (to take the paradigm case) as literally as I would with respect to his claims that representation occurs through similitude, but everyone would have to agree that some such doctrine is at least superficially apparent in his words. ${ }^{8}$

With the spread of Cartesian dualism, the position that representation occurs through resemblance became precarious. Descartes himself thought that though a resembling corporeal image is produced in the pineal gland, "the mind applies itself to this semblance but does not receive it" (AT 7.387, CSM 2.265). Locke held the delicate view that ideas are the immediate object of perception and that some of them resemble qualities

\footnotetext{
${ }^{6}$ On resemblance and representation in Aristotle, see Sorabji (71-79) and Everson 1997.

7 The Christian Platonist theory that we contemplate ideas in the mind of God counts as a rival tradition, and one which Berkeley rejects. With respect to his heroic period of the Principles and the Dialogues, the most important proponent the view is Malebranche. Berkeley's criticisms of his doctrine that we see all things in God may be found in the Second Dialogue (3D 2.213-15).

${ }^{8}$ For an examination of various interpretations, see Brower and Brower-Toland (2008).
} 
inhering in bodies. His position was possible in part because he disavowed knowledge of the underlying nature of ideas and, in particular, disavowed knowledge of whether they were corporeal (Jacovides 1999: \$2.3). By the beginning of the Eighteenth Century, however, Locke's agnosticism was often rejected as undermining good morals and good religion. For example, Leibniz writes to Princess Caroline "it seems that natural religion itself is extremely weakened" in England partly because "Mr. Locke and his sectarians are uncertain at best about whether souls might be material and perish naturally" (A 11, G 7.352). Samuel Clarke replies in defense of English natural religion, "herein [Locke] has been followed only by some Materialists, Enemies to the Mathematical Principles of Philosophy; and who approve little or nothing in Mr. Locke's writings, but his Errors" (A 12, G 7.353).

Berkeley agrees with Leibniz and Clarke that "Locke holds some dangerous opinions” among which he included "the Possibility of Matter's Thinking” (Notebook A \#695). It's a short step from rejecting the possibility that matter might think to rejecting the possibility of corporeal ideas. Berkeley came to the conclusion that not only are ideas incorporeal (in the sense that they don't inhere in material substance), but they can't resemble anything corporeal. Once he concluded that ideas could only resemble other ideas, Berkeley had two choices. Either he could reject the doctrine that resemblance is the mechanism of representation or he could reject the doctrine that we have ideas of mindindependent bodies. He took the second path. What corrupted his capacity to conceive was his retention of the traditional doctrine that representation is through resemblance conjoined with his denial that ideas could resemble anything besides ideas.

\footnotetext{
${ }^{9}$ My point is about atmosphere and not influence: the Leibniz and Clarke sent their letters to Caroline eight or nine years after Berkeley wrote his notebooks.
} 
In $\$ 56$ of the Principles Berkeley offers his own history of ideas to explain why so few people have seen the light of immaterialism, a history that hinges on Descartes's invention of ideas and on Locke's problematic doctrine that some ideas resemble primary qualities. According to Berkeley, since the objects of perception are independent of the will of the perceiver, ordinary people assumed that "ideas or objects of perception had an existence independent of, and without the mind, without ever dreaming that a contradiction was involved in those words" (PHK \56). This ignorance was lifted to some extent by philosophers having plainly seen, that the immediate objects of perception do not exist without the mind, they in some degree corrected the mistake of the vulgar, but at the same time run into another which seems no less absurd, to wit, that there are certain objects really existing without the mind, or having a subsistence distinct from being perceived, of which our ideas are only images or resemblances, imprinted by those objects on the mind (ibid.).

Foremost among the philosophers whom Berkeley has in mind here is Locke, who explicitly asserted both that ideas are the immediate objects of the understanding (Essay 1.1.8, 2.8.8) and also that ideas of primary qualities resemble something in bodies (Essay 2.8.15). ${ }^{10}$ However idiosyncratic this conjunction of views may be, Berkeley sometimes assumes that his opponents would concede that ideas of body represent through resemblance. At one point, he attributes to Hylas the view that there "are real things or external objects perceived by the mediation of ideas, which are their images and representations (3D 2.203).

Berkeley's explanation of why so many people believe in mind-independent bodies is a story of heroic discovery. First, there was widespread error due to the fact that our sensory ideas are independent of our wills, then philosophers realized that the immediate objects of perception were ideas and rightly assumed that if ideas represented mind-independent

\footnotetext{
${ }^{10}$ Locke held an especially salient place in Berkeley's early philosophical outlook. See Notebook A \#\#567, 811 Tipton (18-19).
} 
bodies, it would be through resemblance. It was left to Berkeley to realize that ideas can only resemble other ideas.

\section{The Notion of Body}

These considerations explain why Berkeley denies that we have an idea of mind-independent bodies, but he takes a further step and denies that we can conceive of such a thing at all. At the end of the resemblance argument, he writes, "not to mention the peculiar difficulty there must be, in conceiving a material substance, prior to and distinct from extension, to be the substratum of extension." This is paralipsis—Berkeley does in fact mention the peculiar difficulty in conceiving of material substance. Indeed, if we can't form the idea of extension inhering in a material substratum, it's very difficult to see how we might form the idea of a material substratum in which extension inheres. But Berkeley's point is not merely that there's a difficulty in forming an idea of an extended material substance, but also that we can't conceive of such a thing.

In the Three Dialogues, Philonous claims that the problem with material substance is not "merely that I have no notion of it, but because the notion of it is inconsistent, or in other words, because it is repugnant that there should be a notion of it" (3D 2.232). To the extent that Philonous follows this up with a justification, it is only by asserting, "that ideas should exist in what does not perceive, or be produced by what doth not act, is repugnant" (3D 2.233). Only if something resembling ideas could inhere in matter or if matter could genuinely produce ideas could we possibly represent matter through our ideas. (Locke thought that ideas represent bodies either by resembling them or by being their effects. ${ }^{11}$ )

11 Essay 4.4.4, 4.4.6, Jacovides 1999: §3. 
Since ideas can't inhere in anything that doesn't perceive and since matter is passive, Berkeley concluded that we can't have an idea of material substance. ${ }^{12}$

If we grant the premises, Philonous's argument shows that we have no idea of inert, unperceiving material substance. The conclusion he draws, however, is that "it's repugnant that there should be a notion" of material substance. Since Berkeley thinks that we sometimes have notions where we have no ideas, one might have thought that the absence of an idea doesn't entail the absence of a notion.

What Berkeley says again and again about notions is that having one is equivalent to being able to understand the meaning of a word. E.g. at Principles $\$ 27$, he writes, "we have some notion of soul, spirit, the operations of the mind, such as willing, loving, hating, in as much as we know or understand the meaning of those words." He writes similar things at Principles $\iint 89,140,142$, in the Third Dialogue (3.234), and in Alciphron (7.5). ${ }^{13} \mathrm{I}$ think, following Winkler (1989: 281) and Jonathan Bennett (1968 215-16), that that's all that there is to the theory of notions. Berkeley will say that we have a notion of a thing if and only if we understand the meaning of the word that refers to it. Notions are mostly just façons de parler to avoid the embarrassment of saying that we have no idea of $\mathrm{F}$ but we understand the meaning of the corresponding word.

I don't insist on this minimalistic treatment of notions. Daniel Flage (180-92) argues that Berkeleian notions are the acts of understanding which we carry out when understand a word without an idea. Since there's no reason to deny that Berkeley believes that there are such acts, I don't see any point in arguing over whether his talk of notions is just an indirect

\footnotetext{
${ }^{12}$ As I mentioned earlier, Berkeley believes that ideas can come to signify other ideas through stipulation or customary association. But such associations can't get us out of our own minds; they are only possible between objects of our immediate acquaintance.

13 The list comes from Flage 4-5.
} 
way of saying that such acts occur or whether he actually intended to identify notions with these acts as a matter of metaphysics.

What I do insist on is that these acts of understanding are constrained by his semantic framework. The central features of that framework are acquaintance and resemblance. Berkeley assumes that if ideas did represent minds, the mechanism would be would be through resemblance (PHK $₫ 27$, cf. $\$ \$ 135,137,138$, Alciphron 3.292; Bennett 1971: 214, Winkler 1989: 20, Cummins 2005 207). Even though we can't use ideas to represent other minds, Berkeley still believes that we represent them with resembling proxies (Adams 59-60, Winkler 1989: 282-83, Cummins 2005: 201, 209). According to him, in the same way that we conceive of other people's ideas as resemblances of our own, we likewise conceive of other spirits as resemblances of our own:

as we conceive the ideas that are in the minds of other spirits by means of our own, which we suppose to be resemblances of them: so we know other spirits by means of our own soul, which in that sense is the image or idea of them, it having a like respect to other spirits, that blueness or heat by me perceived hath to those ideas perceived by another (PHK \140, cf. 3D 2.232).

Here we get an account of how we represent ideas in other minds (as resemblances of our own ideas) and also an account of how we represent other minds (as resemblances of our own mind). Notice that each soul is, in a sense, 'the image or idea' of other spirits. One's own soul represents other souls as one's own ideas represent ideas in other minds. As Adams writes, "self-awareness provides us with a sort of image for conceiving of other spirits" (61). 
The nature of our acquaintance with own souls is a matter of controversy among commentators. ${ }^{14}$ Berkeley plainly doesn't think that this acquaintance works through perception. In Section 27 of the Principles he writes, "such is the nature of spirit or that which acts, that it cannot be of it self perceived, but only by the effects which it produceth." This is what we should expect from him given his doctrine that the being of ideas is to be perceived (PHK \3) and his doctrine that spirits and ideas are radically dissimilar. If the esse of ideas consists in their being perceived, we wouldn't expect other, radically different things to participate in that esse. More generally, if spirits and ideas share no features, then they don't share the feature of being perceived. Berkeley's commitment to the dissimilitude of spirits and ideas runs so deep that he denies that they may both be said to exist in the same sense or that they may be said to be objects of knowledge in the same sense: "Spirits and ideas are things so wholly different, that when we say, they exist, they are known, or the like, these words must not be thought to signify anything common to both natures" (Principles, $\$ 142$, cf. \89, Notebook A \#\#643, 658).

On the other hand, it seems plain that, at least after the notebooks, Berkeley believes that we have some sort of self-consciousness. In the Dialogues, he writes, "How often must I repeat, that I know or am conscious of my own being; and that I my self am not my ideas, but somewhat else, a thinking active principle that perceives, knows, wills, and operates about ideas" (3D 2.233). This self-knowledge presents us with the thing signified by first person singular pronouns: "I know what I mean by the terms I and myself; and I know this immediately, or intuitively, though I do not perceive it as I perceive a triangle, a colour, or a sound" (3D 2.231).

\footnotetext{
14 A debate including, among others, Adams, Tipton 262-71, Pitcher 213-23, Flage 150-54, and Cummins 2005 : 204-09.
} 
Berkeley seems to have believed in a stepladder of acquaintance, beginning with ideas, and working its way inward and upward. Some such belief appears behind his sympathetic exposition of Proclus:

if the soul look abroad, she beholds the shadows and images of things, but returning into herself she unravels and beholds her own essence. At first she seemeth only to behold herself, but having penetrated farther she discovers the mind. And again, still farther advancing into the innermost sanctuary of the soul, she contemplates the $\theta \varepsilon \hat{\omega} \nu$ Y'́vos [divine kind] ${ }^{15}$. And this, he saith, is the most excellent of all human acts, in the silence and repose of the faculties of the soul to tend upwards to the very Divinity, to approach and be closely joined with that which is ineffable and superior to all beings (Siris \$333, cf. Siris \$303).

According to Berkeley when the soul looks out at its ideas, it sees shadowy dependencies.

This is the first step to the kind of introspective knowledge that can show us something divine and which allows us to contemplate God.

Indeed, Berkeley applies his account of our representation of other minds most often to God. In the Third Dialogue he argues that since "ideas are perfectly inert," and God is "an agent, a being perfectly active," it follows that "no idea therefore can be like unto, or represent the nature of God" (2.231). That is, since ideas don't resemble God, they can't represent him. On the other hand,

taking the word idea in a large sense, my soul may be said to furnish me with an idea, that is, an image, or likeness of God, though indeed extremely inadequate, For all the notion I have of God, is obtained by reflecting on my own soul heightening its powers, and removing its imperfections (2.231-32).

Because our own souls are likenesses of God, we can use them to represent God.

The doctrines shape Berkeley's understanding the imago dei doctrine. In a sermon on the mystery of Godliness, Berkeley preaches,

It is evident that there are two parts in the composition of man: The mind which is pure and spiritual, which is made in the image of God, and which

15 Alternatively: 'race of the gods' 
we have in common with the angels: and the corporeal part containing the senses and passions which we have in common with brute beasts. The former tends to the knowledge and love of God as its true center, to vertue piety and holiness, to all things excellent and praise-worthy; the later inclines to the world, to sensible objects, to carnal things such as may gratify our grosser affections and appetites (7.88, see also 3D 2.232).

Our sensory ideas and passions aren't like anything in God. God has no passions and knows nothing through sensation, since "sense is a passion; and passions imply imperfection" (Siris \$289). On the other hand, our minds are like God, insofar as they are knowing, virtuous, and pious.

Consider Berkeley's account of the corruption of ethics in the Principles: a man may be just and virtuous, without having precise ideas of justice and virtue. The opinion that those and the like words stand for general notions abstracted from all particular persons and actions, seems to have rendered morality difficult, and the study thereof of less use to mankind. And in effect, the doctrine of abstraction has not a little contributed towards spoiling the most useful parts of knowledge (PHK \$100).

This is a diatribe against abstraction and should be understood in conjunction with other similar arguments in Berkeley. A significant difference, however, is that he usually inveighs against abstract ideas and tells us that true thoughts of generality are gotten by considering particular ideas as representatives of a resembling class. Here Berkeley inveighs against abstracted notions and tells us that we ought to attend to particular persons and actions. This suggests that Berkeley's account of thoughts of generality in ethics works like his account of general ideas: a particular act or spirit is taken as representative for all other actions or spirits that resemble it in some relevant respect.

In de Motu, Berkeley argues that we can't conceive of absolute space through pure intellect, "since that faculty turns only to spiritual and unextended things, things of a kind 
with our minds and their characters, passions, virtues, and the like" $(\$ 53) .{ }^{16}$ His argument is that since pure intellect only represents things similar to our minds and their modes, it can't represent absolute space. The assumption behind the argument is that pure intellect is merely our ability to contemplate minds, passions, and virtues by considering them as resemblances of what we find inside ourselves.

These considerations explain why Berkeley is willing to move from the premise that we have no idea of mind-independent body to the conclusion that we have no notion of mind-independent body. We lack a notion of material substance because we can't conceive of it, and we can't conceive of it because we have no internal resembling proxy for it. If anything were our internal resembling proxies for material substances, it would be our ideas of bodies.

\section{The Master Argument Revisited}

Now that we've seen why Berkeley's theory of representation doesn't allow us to conceive of mind-independent bodies, let us consider Berkeley's master argument. In the Principles, Berkeley offers the following challenge to his readers:

if you can but conceive it possible for one extended moveable substance, or in general, for any one idea or anything like an idea, to exist otherwise than in a mind perceiving it, I shall readily give up the cause: And as for all that compages of external bodies which you contend for, I shall grant you its existence, though you cannot either give me any reason why you believe it exists, or assign any use to it when it is supposed to exist (PHK \22)

The specific version of the challenge is to conceive an extended moveable substance existing independently of a mind. The more general version of the challenge is to conceive of an idea or anything like an idea existing independently of a mind. Berkeley takes the second challenge to be a

\footnotetext{
${ }^{16}$ Fugit [spatium absolutum] insuper intellectum purum, quum facultas illa versetur tantum circa res spirituals \& inextensas, cujusmodi sunt mentes nostrae earumque habitus, passions, virtutes \& similia.
} 
more general version of the first because he takes meeting the second to be a necessary condition for meeting the first. More precisely, he takes the possibility of the object of the second conceivability challenge to be a pre-condition for meeting the first conceivability challenge. The reason Berkeley considers the mind-independent existence of an idea or something like an idea to be a precondition for conceiving of an extended substance is that he assumes that if we could conceive of such a thing it would be through a resembling idea.

Winkler observes this implication of the texts, writing that the general challenge suggests that the materialist is assumed to agree that representation involves resemblance. And Berkeley's response to the interlocutor's attempt is that he or she has done no more than frame 'certain ideas' in the mind, which suggests that the materialist is assumed to agree to conceive of a thing is to call up a mind-dependent object (1989: 186).

Alas, Winkler does not allow himself to be convinced by his own insight: "I do not think that Berkeley wants to make the crude point that an idea, being mind-dependent, cannot mirror the independence of its intended object. There is no evidence that he has such an argument in mind." But, I cry, the general challenge just is evidence that he has such an argument in mind.

I think that something like Winkler's crude argument underlies Berkeley's inability to conceive of unperceived bodies. I will state it even more bluntly. According to Berkeley, because our ideas can't resemble mind-independent objects, they can't represent mindindependent objects. Even setting the general challenge aside, it seems to me wrong to say that that there isn't any evidence that Berkeley has the crude argument in mind. The crude argument that Winkler doesn't want to attribute to Berkeley is what I've called the Resemblance argument, which, as we have seen, Berkeley plainly advances in the Dialogues. As we have also seen, Berkeley offers positive accounts of our representation of real beings, perceptions in other mind, other minds, and God in which resemblance plays a central role. 
He advances negative arguments showing that we have no ideas of mind, God, and activity which rest on the premise that our ideas can't resemble such things. In going over the central place of resemblance in Berkeley's philosophy, I am not telling Winkler anything he hasn't already published. Indeed before recoiling from attributing the crude argument to Berkeley, Winkler had written, "Berkeley believes that representation can only be a matter of resemblance" (138).

Given the textual support for attributing the Resemblance argument to Berkeley, we can only ask why Winkler resists the attribution. And the answer, so far as I can tell, is that the argument seems 'crude.' Three things may be said in defense of Berkeley's sophistication. First, as his discussion of the bust of Caesar in the first Dialogue makes clear, Berkeley believes resemblance is a necessary but insufficient condition for representation. Hylas and Philonous agree that merely looking at a statue doesn't suffice to have "your thoughts directed to the Roman Emperor," but that the resemblance needs to be supplemented by "reason and memory" (3D 2.204). Second, Berkeley's theory of general ideas, where particular ideas are taken as representatives of a resembling class depends on likeness, but no one would call it crude. Third, the main contemporary alternatives to saying that representation is through resemblance-Epicurean causal theories, Descartes's relative silence on the matter, Malebranche's doctrine that we see all things in God-are not actually any subtler than Berkeley's account.

Winkler has his own positive account of how Berkeley came to be convinced by the Master Argument. The meaning of 'existence' as the term is applied to sensible objects 'is to be perceived or perceivable," Winkler (1989: 187) writes. On that definition, it's a contradiction in terms to suppose that a sensible object might exist independently of perceptibility. I am actually quite sympathetic to this reading, as sympathetic as one can be 
while advancing a rival view. It seems to me that this is pretty much the right way to read \24 of the Principles, ${ }^{17}$ the section that comes right after the Master Argument. On the other hand, Winkler's reading does not explain what Berkeley means by the more general challenge in the Master Argument itself. Nor does it explain what Berkeley thinks his interlocutors are doing when they think they are conceiving of unperceived bodies. In addition Berkeley isn't explicitly concerned with meaning of the word 'existence' in the Three Dialogues' version of the Master Argument.

This is important not just for the sake of understanding his dialectical intentions, but also for tracing the origins of Berkeley's faith in the argument. Our earlier examination of his diagnosis of the philosophers' belief in material substance showed that the principle that ideas can only resemble other ideas seemed to him to be a decisive step on the road to idealism. Colin Turbayne (\$2) reached the same conclusion based on a careful examination of Berkeley's notebooks.

Any revisionist reading of $₫ 22$ of the Principles has to offer revisionist readings of $\$ 23$ and of the Master Argument as it stands in the Three Dialogues. In \23, part of Berkeley’s reply to his interlocutor's claim that he can imagine books in a cabinet with no one perceiving them is,

When we do our utmost to conceive the existence of external bodies, we are all the while only contemplating our own ideas. But the mind taking no notice of itself, is deluded to think it can and doth conceive bodies existing unthought of or without the mind: though at the same time they are apprehended by or exist in itself.

The last clause is a bit hard to parse. If we trace back the referents we see that we may unpack the sentence as, at the same time that someone deludes himself into thinking that he

\footnotetext{
${ }^{17}$ I would add the caveat that Berkeley uses the expression "absolute existence" in $\$ 24$, and I believe that for Berkeley the absolute existence of a body (as opposed to its hypothetical existence) requires actual perception and not mere perceptibility (3D 2.252-54).
} 
conceives of a mind-independent bodies, the conceived bodies are apprehended by the mind or exist in the mind. Is the 'or' in that clause supposed to mean 'or, in other words' or does it express a disjunction of two possibilities?

As we have seen, in $\$ 33$ of the Principles, Berkeley asserts that our relatively faint and indistinct ideas of the imagination represent our vivid, distinct, and coherent ideas by copying and resembling them. In $\$ 140$, he asserts that we represent ideas in the minds of others by considering them as resemblances of our own ideas. If we put these doctrines together, they imply that Berkeley believes that we can conceive of vivid perceptions in other spirits as resemblances of our own ideas of the imagination. So it's possible for us to conceive of ideas that are perceived by someone else. Based on statues and descriptions, we might, for example, form ideas of Caesar's nose. These would be ideas of the imagination that resemble the real thing in the minds of perceivers in first century Rome. If I have understood Berkeley right, in such a case, he would say that we apprehend the real thing, Caesar's nose, but it doesn't exist in our minds. The disjunction near the end of $₫ 23$ is genuine disjunction, you can apprehend Caesar's nose without Caesar's nose existing in your mind.

With this in mind, let us turn to the Master Argument as presented in the Three Dialogues. Hylas has claimed that he can "conceive of a tree or house existing by itself, independent of, and unperceived by any mind whatsoever" (3D 2.200). Philonous presses him on this claim: "Is it not . . . a contradiction to talk of conceiving a thing which is unconceived?

HYLAS. It is.

PHILONOUS. The tree or house therefore which you think of, is conceived by you.

HYLAS. How could it be otherwise? 
PHILONOUS. And what is conceived, is surely in the mind.

HYLAS. Without question, that which is conceived is in the mind.

PHILONOUS. How then came you to say, you conceived a house or tree existing independent and out of all minds whatsoever?

HYLAS. That was I own an oversight . . But now I plainly see that all I can do is to frame ideas in my mind. I may indeed conceive in my own thoughts the idea of a tree, or a house, or a mountain, but that is all. And this is far from proving, that I can conceive them existing out of the minds of all spirits.

The plain, unsophisticated reader would surely assume that when Hylas grants that 'that which is conceived is in the mind' the concession is supposed to be that 'if S conceives of $\mathrm{x}$, then $\mathrm{x}$ is in S's mind. ${ }^{, 18}$ If that were the premise, then the conclusion should be solipsism: Hylas can't conceive of any body as existing outside of his mind (Hicks 138-40, Tipton 161, Pitcher 112-13). Such a reader would be nonplussed to find Philonous considering and emphatically rejecting this sort of solipsism in the Third Dialogue and asserting that he can conceive of a bodies existing in other minds and not in his own. Hylas asks, "Supposing you were annihilated, cannot you conceive it possible, that things perceivable by sense may still exist?" Philonous replies, "I can; but then it must be in another mind. When I deny sensible things an existence out of the mind, I do not mean my mind in particular, but all minds" (3D 2.230).

But we are not plain, unsophisticated readers. We are rather scholars who know about $\iint 33$ and 140 of The Principles of Human Knowledge. Berkeley believes that we conceive of real bodies with resembling ideas, and that we can conceive of bodies in the minds of other spirits by considering our own ideas as resemblances of those bodies. Berkeley believes that ideas only resemble other ideas and that ideas must exist in some mind or

\footnotetext{
18 Reasonably enough, the unsophisticated reading is the one usually attributed to Berkeley. It is well criticized by Hicks (115-19), Tipton (158-66), and Pitcher (111-15) among others.
} 
other. Thus, Berkeley is committed to asserting that if $\mathrm{x}$ is a body, and $\mathrm{S}$ conceives of $\mathrm{x}$, then $\mathrm{x}$ exists in some spirit or other. He is not committed to asserting that if $\mathrm{x}$ is a body, and $\mathrm{S}$ conceives of $\mathrm{x}$, then $\mathrm{x}$ exists in $\mathrm{S}$. So, when Philonous asserts that he can conceive of bodies unperceived by him and existing only in the minds of others, that remark is compatible both with Berkeley's theory of representation and with the letter of the Master Argument.

Once we take a second look at the interlocutors' responses to the Master Argument in light of Berkeley's theory of representation, we see that something subtler is going on that what we get on a first reading without context. Consider Hylas's account of how he came to mistakenly think that he conceived of a sensible object existing mind-independently:

but stay, let me consider what led me into it.-It is a pleasant mistake enough. As I was thinking of a tree in a solitary place, where no one was present to see it, methought that was to conceive a tree as existing unperceived or unthought of, not considering that I myself conceived it all the while. But now I plainly see, that all I can do is to frame ideas in my own mind (3D 2.200).

The point is not that we can only conceive of ideas in our minds. As we have seen, Berkeley thinks that we can conceive of perceptions in other minds and that we can conceive of other minds, including God.

Berkeley is rather offering an account of what happens when we conceive of bodies. Hylas forms an idea of a tree. Hylas's first-person authority over what he has conceived of extends only to reporting the presence and character of his ideas. He knows for sure that he has formed the idea of a tree, but whether that idea represents something independent of the mind is not something that he can tell through the same sort of introspection. It is left to the semanticist and the philosopher of mind to recognize that ideas represent through resemblance and that ideas can only resemble other ideas. 
I have up to this point explained why Berkeley believes that he can't conceive of unperceived bodies. He thinks that any such conception would be through resembling ideas, and ideas can only resemble other ideas. Conception is a delicate and suggestible faculty. Because Berkeley believed that he couldn't conceive of unperceived bodies, he lost the ability to conceive of unperceived bodies. When he looked inside himself and tried to conceive of mind-independent bodies, he could find no more than Hylas did, images of books on a shelf or trees in a park. Such imagery only counts as conceiving of a mind-independent body if you let it, and Berkeley didn't let it.

In defending the worry that the finite cannot understand the infinite, Wittgenstein calls for something like an audit of infinitary mathematics. The question of how a finite calculation can allow us to understand the infinite, he writes is well worth an investigation. And this is to be compared to a chartered accountant's strict examination and clarification of a company's business practices. The goal is a surveyable comparative presentation of all applications, illustrations, and interpretations of the calculation. ... 'The finite cannot understand the infinite' means here: It cannot work in the way you, with characteristic superficiality, are presenting it. .... You don't understand, that is, you don't survey, your transactions and it's as if you project your lack of understanding into the idea of a medium in which the most astonishing things are possible (\$273).

Berkeley attempted this sort of investigation into the workings of our ideas. Only good things would come from a true theory of representation, but thinking about the theory of representation is no easier than thinking about the things themselves. Berkeley imposed excessively tight strictures on representation and the conceivable boundaries of his world shrank as a consequence. 


\section{Reply to Smalligan}

I'm grateful to Jennifer Smalligan for her incisive and insightful criticisms. They raise at least four questions I should answer. First, does Berkeley draw the conclusion from the Resemblance Argument that we can't have an idea of extension that represents a quality inhering in a mind-independent body? Yes, Philonous concludes, "no . . mode of extension, which we can either perceive or imagine, or have any idea of, can be really inherent in matter." If we can't have any idea of a mode of extension that really inheres in matter, then we can't have an idea that represents extension as really inherent in matter.

That answer is quick, because I think I'm right. There's no reason to fuss over which variety of extension Berkeley had in mind, because there's no reason to believe that he thought that ideas could resemble non-ideas with respect to any sort of extension whatsoever. My answer to the second question is slow, because Smalligan is right to criticize me for a lack of specificity. What strength of what she calls 'The Resemblance Principle' should we attribute to Berkeley? It seems to me that in order to make sense of his general challenge it suffices to appeal to what she calls 'Resemblance Principle 1.'

Principle 1 is that in order for an idea to represent something, it has to resemble that thing in some respect or other. Smalligan rightly calls this version of the Principle "pretty innocuous," since most philosophers would grant that any two entities would resemble one another with respect to some quality or other (e.g, existing, conceivable, or not identical to Pope Clement the Eleventh). But Berkeley is not like other philosophers. When he writes that "an idea can be like nothing but an idea" he means it in full generality: ideas can't be like nonideas in any respect whatsoever. 
It's hard to prove this directly for every kind of thing that might be, but we have excellent evidence that he thinks that ideas don't resemble spirits in any respect whatsoever. Given his ontology, that should be close enough.

In $\$ 137$ of Part I of the Principles, Berkeley considers an objection to his argument that we have no idea of spirit: "But, perhaps you will say, that though an idea cannot resemble a spirit, in its thinking, acting, or subsisting by itself, yet it may in some other respects: and it is not necessary that an idea or image be in all respects like the original." Berkeley replies, "if it does not in those mentioned, it is impossible it should represent it in any other thing. Do but leave out the power of willing, thinking, and perceiving ideas, and there remains nothing else wherein the idea can be like a spirit” (PHK§138). This dissimilitude extends to existence and to being known. Berkeley writes, "Spirits and ideas are things so wholly different, that when we say, they exist, they are known, or the like, these words must not be thought to signify anything common to both natures. There is nothing alike or common in them" (PHK \142). Ideas and spirits don't just exist in different ways; they exist in different senses of the word 'exist'.

Even so, as Smalligan says, Resemblance Principle 1 is quite weak, and it's worth asking what version, if any, of what she calls Resemblance Principle 2 Berkeley would endorse. Let me suggest: for an idea to represent something as being F, it needs to be F or to have a determinable of which F is a determination. Heeding Smalligan's call for precision shows that I was wrong to identify the Resemblance argument with the argument that Winkler calls crude. The resemblance argument may be cast as follows: Since ideas can't resemble mindindependent bodies with respect to being extended or being moveable, they can't represent them as being extended or moveable. In contrast, the relevant quality in the argument that Winkler resists attributing to Berkeley is mind-independence. 
I modified Smalligan's Resemblance Principle 2 along the lines she suggested in her discussion of Resemblance Principle 1; that is, I've attributed to Berkeley the requirement that our representational images share determinable qualities in order for us to conceive of the corresponding determinate quality. He thinks we can use our own soul as a representational proxy to conceive of God as omnipotent, even though we have a much smaller amount of power. The modification avoids the danger of solipsism, since the determinate depending on George's mind (which none of my ideas have) falls under the determinable depending on someone's mind (which all of my ideas have).

Third question: is the Likeness Principle a premise of Berkeley's Master Argument? My considered answer is no. Thus, as Smalligan rightly argues, I made a mistake when I attributed to Berkeley the view that only semanticists and philosophers of mind could decide whether mind-independent bodies are inconceivable and I made another mistake when carelessly identified the Resemblance Argument with Master Argument. To be careful, the extended version of the Resemblance Argument has as its conclusion the proposition that we can't conceive of material substance. The Master Argument takes as an immediately obvious premise that we can't conceive of an extended substance existing independently of the mind and moves to the conclusion that we ought not believe in such things, pausing only to explain away the delusion that we can conceive of such things. The thesis of my paper is that Berkeley couldn't conceive of mind-independent bodies because he had adopted a particular theory of representation. The general challenge shows that Berkeley was aware of what lay behind his inability to conceive of such things, but it doesn't show that the Likeness Principle is a premise in the argument.

Fourth, Smalligan asks whether it follows from my thesis that Berkeley corrupted his capacity to conceive "that inconceivability is no indication of impossibility at all". I don't 
think that it follows or that it's true. I believe that if something is inconceivable, then, ceteris paribus, it's probably impossible, and even more probably false. But anyone who isn't an idealist and who concedes that Berkeley couldn't conceive of mind-independent bodies will have to grant that inconceivability is not a guarantee of impossibility. My contribution is to describe one way in which inconceivability can go astray as a guide to falsehood.

\section{Bibliography}

Adams, Robert Merrihew. 1973. “Berkeley’s ‘Notion’ of Spiritual Substance,” Archiv für Geschichte der Philosophie 55: 47-69.

Bennett, Jonathan. 1971. Locke, Berkeley, Hume: Central Themes. Oxford: Clarendon Press. ---- 1982. “A Note on Interpretation,” Canadian Journal of Philosophy 12: 753-55.

Brower, Jeffrey and Susan Brower-Toland. 2008. “Aquinas on Mental Representation: Concepts and Intentionality," The Philosophical Review 117: 193-243.

Cummins, Phillip D. 1968. "Berkeley's Likeness Principle," in Locke and Berkeley: A Collection of Critical Essays, edited by C.B. Martin and D.M. Armstrong. Notre Dame: University of Notre Dame Press.

----- 2005. "Berkeley on Minds and Agency," in The Cambridge Companion to Berkeley, edited by Kenneth P. Winkler. Cambridge: Cambridge University Press.

Everson, Stephen. 1997. Aristotle on Perception. Oxford: Clarendon Press.

Flage, Daniel E. 1987. Berkeley's Doctrine of Notions: A Reconstruction Based on bis Theory of Meaning. London: Croom Helm.

Hicks, Dawes. 1932. Berkeley. London: Ernest Benn Limited. 
Jacovides, Michael. 1999. "Locke's Resemblance Theses," The Philosophical Review 108: 46196.

----- 2007. “Locke’s Distinctions between Primary and Secondary Qualities," The Cambridge Companion to Locke's Essay Concerning Human Understanding, edited by Lex Newman. Cambridge: Cambridge University Press.

Pitcher, George. 1977. Berkeley. London: Routledge \& Kegan Paul.

Putnam, Hilary. 1981. Reason, Truth, and History. Cambridge: Cambridge University Press. Ryan, Todd. 2006. “A New Account of Berkeley's Likeness Principle,” British Journal for the History of Philosophy 14: 561-80.

Sorabji, Richard. 1974. "Body and Soul in Aristotle," Philosophy 49: 63-89.

Tipton, Ian. 1994. Berkeley: The Philosophy of Immaterialism. Bristol: Thoemmes Press.

Turbayne, C.M. 1956. “The Influence of Berkeley’s Science on His Metaphysics,” Philosophy and Phenomenological Research 16: 476-87.

Winkler, Kenneth P. 1989. Berkeley: An Interpretation. Oxford: Clarendon Press.

----- "Berkeley and the Doctrine of Signs," The Cambridge Companion to Berkeley, edited by Kenneth P. Winkler. Cambridge: Cambridge University Press.

Wittgenstein, Ludwig. 1967. Zettel, edited by G.E.M. Anscombe and G.H. von Wright, translated by G.E.M. Anscombe. Berkeley: University of California Press. 